\title{
Human gonadotropin-releasing hormone receptor-activated cellular functions and signaling pathways in extra-pituitary tissues and cancer cells (Review)
}

\author{
ARTURO AGUILAR-ROJAS ${ }^{1}$ and MAIRA HUERTA-REYES ${ }^{2}$ \\ ${ }^{1}$ Unidad de Investigación Médica en Medicina Reproductiva, Unidad Médica de Alta Especialidad (UMAE) en \\ Ginecología y Obstetricia No. 4 'Dr. Luis Castelazo Ayala', Instituto Mexicano del Seguro Social (IMSS), \\ Av. Río Magdalena No. 289, Col. Tizapán San Ángel, 01090 México, D.F.; ${ }^{2}$ Centro de Investigación \\ Biomédica del Sur (CIBIS), IMSS, Argentina No. 1, Col. Centro, 62790 Xochitepec, Morelos, México
}

Received March 16, 2009; Accepted May 20, 2009

DOI: $10.3892 /$ or_00000525

\begin{abstract}
Human gonadotropin-releasing hormone receptor (GnRHR) and its natural ligand human gonadotropin-releasing hormone $(\mathrm{GnRH})$ were initially described as signaling complexes that play a key role in reproductive functions. By binding to specific receptors present on pituitary gonadotropes, $\mathrm{GnRH}$ regulates the sperm and ovum maturation, as well as steroidogenesis within the context of the hypothalamushypophysis axis. The expression of $\mathrm{GnRH}$ and its receptor has clearly been established in many extra-pituitary organs. Some of them are tumors from non-reproductive tissues such as liver, larynx, pancreas, colon, lymphoma, kidney, skin, blood and brain as well as tissues from reproductive track, for example ovary, endometrium, prostate and breast or tumors derived from these organs. Expression of GnRH and its receptor in these organs has gained much attention and several research groups have established their role during cell proliferation and cell motility. Although the signaling pathways and their effector proteins in these samples remain unclear, the molecular mechanism employed for GnRH and its receptor in extra-pituitary tissues could be related with non-classical GnRHR-signaling pathways. In the present review, we explore the vast literature reported on $\mathrm{GnRH}$ and GnRHR principally in tumors, describing how cross-talk between GnRHR and growth factor receptor, the coupling between GnRHR and many $\mathrm{G}$ proteins depending on cell
\end{abstract}

Correspondence to: Dr Arturo Aguilar-Rojas, Research Unit in Reproductive Medicine, IMSS, Unidad Médica de Alta Especialidad (UMAE) en Ginecología y Obstetricia No. 4 'Dr. Luis Castelazo Ayala', Sexto piso, Av. Río Magdalena No. 289, Col. Tizapán San Ángel, 01090 México, D.F., México

E-mail: a_aguilar@correo.unam.mx

Key words: human gonadotrophin-releasing hormone, human Gonadotrophin-releasing hormone receptors, cell proliferation, cell motility, cytoskeleton context, and the regulation of several proteins associated with cell proliferation and cell motility are employed by GnRHR/ $\mathrm{GnRH}$ to regulate their extra-pituitary activities.

\section{Contents}

1. Introduction

2. Function of GnRHR in extra-pituitary tissues

3. Action of GnRHR during cell motility and invasion

4. Conclusions

\section{Introduction}

Function of GnRHR and GnRH in pituitary. Human gonadotropin-releasing hormone type I [denominated here as GnRH and also known as Luteinizing hormone-releasing hormone $(\mathrm{LHRH})]$, is a hypothalamic decapeptide $(1,2)$. It specifically binds to the gonadotropin-releasing hormone receptor type I (referred here as GnRHR and also known as LHRH receptor), which is a member of G-protein coupled receptors (GPCR) $(2,3)$. In conjunction, both molecules comprise one of the most important signaling complexes that control sperm and ovum maturation, as well as steroidogenesis in gonads, by means of production and release of pituitary gonadotropins, luteinizing hormone ( $\mathrm{LH})$ and Follicle-stimulating hormone (FSH) $(1,2)$. LH and FSH are structured by two non-covalently linked $\alpha$ and $\beta$ subunits (4). Within a species, $\alpha$-subunits are identical, while $\beta$-subunits differ and confer physiological heterodimeric hormone specificity.

After $\mathrm{GnRH}$ receptor activation, synthesis and release of the $\alpha$ and the two separate $\beta$ chains of FSH and LH are promoted (5). At present, many molecular details employed during this signaling process are well known. GnRH is produced in anterior hypothalamus while GnRHR is expressed mainly in gonadotrope membrane in adenohypophysis (6). After $\mathrm{GnRH}$ binds, GnRHR via $\mathrm{G}_{\mathrm{q} / 11}$ protein produces Phospholipase C- $\beta$ (PLC) activation with the consequent 


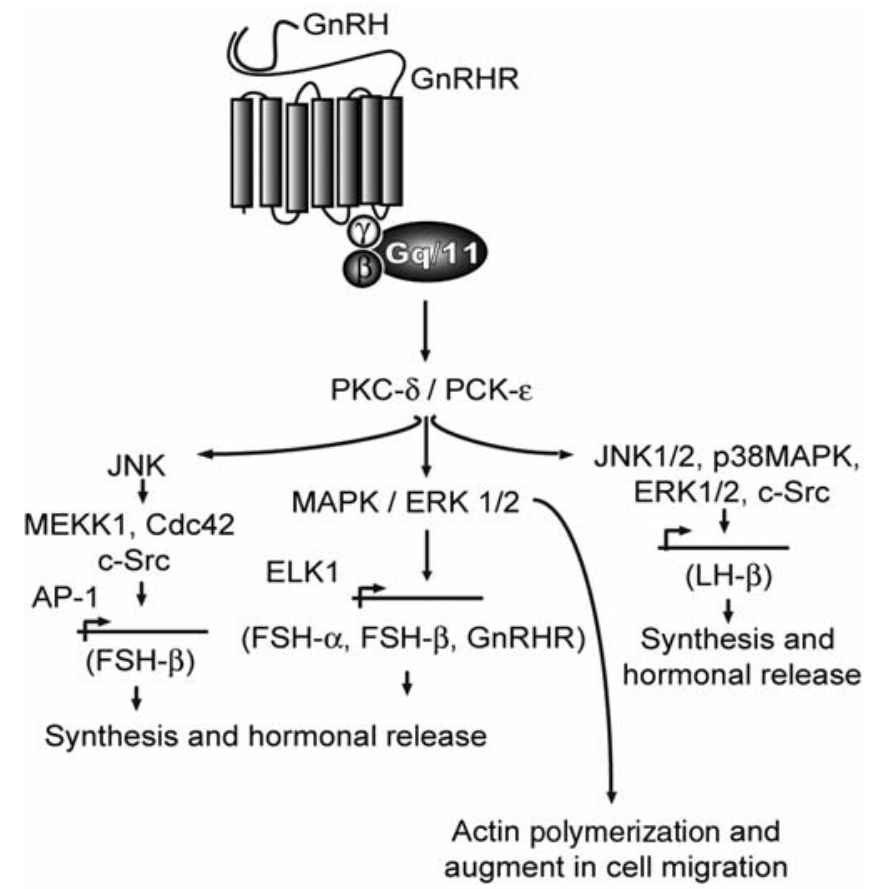

Figure 1. The signaling pathway activated after gonadotropin-releasing hormone receptor (GnRHR) activation in pituitary cells. The binding between gonadotropin-releasing hormone $(\mathrm{GnRH})$ and GnRHR, produce $\mathrm{PKC}$ activation and the concomitant production and release of $\alpha$ and $\beta$ subunit of LH and FSH. GnRHR activation caused changes in cellular morphology derivative by actin polymerization after ERK1/2 activity with a high increase in cell motility as well as detach cell behavior. Activation is represented by solid arrows $(\downarrow)$.

increase in second messengers inositol 1,4,5-triphosphate (IP3) and diacylglycerol (DAG), and calcium $\left(\mathrm{Ca}^{2+}\right)$ release. This increase in DAG and $\mathrm{Ca}^{2+}$ is able to activate at PKC- $\delta$ or PKC- $\varepsilon$ (7), triggering the synthesis and release in pulse fashion of LH and FSH via some members of the mitogen-activated protein kinase family (MAPK) $(7,8)$ (Fig. 1).

Gene expression of $\mathrm{LH}$ and FSH by GnRHR via MAPK pathway. The MAPK family is composed of several isoforms in mammals: Extracellular signal-regulated kinase (ERK) (ERK1/2, -3/4, -5, -7/8); Jun N-terminal kinase [(JNK)1/2/3]; p38 MAPK [a/b/g(ERK6)/d], and big MAPK (BMK, ERK5) (8-12). Each of these signaling pathways is constituted of a few classes of serine/threonine kinase proteins, which are activated in a sequential manner. Their principal function is to regulate gene expression either by activating nuclear transcription factor or by phosphorylating down-stream cytoplasmatic kinases (13). MAPK pathways are activated by many stimuli, including receptor tyrosine kinases (RTK) and GPCR (14). MAPK activation for RTK is associated with many effector molecules, such as Grb2, an adaptor molecule, and the guanine exchange factor (GEF) mSos. These proteins produce Ras activation followed by Raf-1, MAPK kinase (MAPKK; MEK), and MAPK. In the case of GPCR, these receptors are linking with MAPK by several systems, including PKC-dependent and -independent pathways, through the sequential activation of the proteins $(15,16)$.

The gene expression of LH and FSH subunits via GnRHRMAPK has been demonstrated by several assays carried out in pituitary cells or in the $\alpha \mathrm{T} 3-1$ gonadotrope-derived cell line. These reports showed that either ERK1/2 $(8,17)$ or MAPK are markedly activated during GnRH-pulse activation $(18,19)$ via PKC $(20-23)$ with concomitant mRNA expression of FHS- $\alpha$, FSH- $\beta$ subunit, as well as mRNA of GnRH receptor $(19,24)$ (Fig. 1). In the case of $\alpha$-subunit, this transcription gene is produced at least by two unrelated response elements. One is a permissive GnRH tissue-specific enhancer designated by pituitary glycoprotein hormone basal elements (PGBE), which is able to bind the transcription factor ELK1 (24), and the other comprises the GnRH-responsive element (GnRH-RE) which is sufficient to allow GnRH responses $(25,26)$.

Another MAPK family member that is activated by $\mathrm{GnRH}$ is JNK (27). This signaling pathway reported by FSH- 3 subunit employs the AP-1 transcription factor, which is activated by the tyrosine kinase $\mathrm{c}-\mathrm{Src}$, the small $\mathrm{G}$ protein Cdc42 and MEK kinase 1 (MEKK1) $(27,28)$ (Fig. 1). It has also been shown that multiple MAPK-family members, such as JNK 1/2, p38MAPK, and ERK1/2, as well as c-Src, are involved in GnRH-promoted LH $\beta$-subunit gene expression (29) (Fig. 1).

MAPK activation through GnRHR has been demonstrated by gonadotropes, but the signaling cascade could depend on cell type (17). For GT1-7, a hypothalamus-derived cell, ERK activation occurs via cross-talking between GnRHR and epidermal growth factor receptor (EGFR) (30). Once ERK protein is activated, the canonical pathway begins. For other cell lineages, cellular response via GnRHR-MAPK is very different. In the case of HEK293 cells, ERK activation depends on its binding to focal adhesion kinase (FAK) and c-Src at the adhesion complex that produces cytoskeleton remodeling (31). At the same time, in several cell lines, GnRHR is also able to be coupled with several G proteins (32-35). For COS-7 cells, MAPK regulation couples with $\mathrm{G}_{\mathrm{i}}$ protein and EGFR, c-Src, ERK and JNK as the next step in signal transduction $(36,37)$.

\section{Function of GnRHR in extra-pituitary tissues}

Synthesis and release of FSH and LH in pituitary cells is the principal GnRH receptor function. However, in non-pituitary tissues, tumor derived from non-reproductive tissues and tumors from reproductive tissues (ovary, endometrium, prostate and breast) (38), GnRH and GnRHR are expressed and associated with many novel cellular responses.

GnRHR in non-pituitary tissues. Identification of GnRH and GnRHR mRNA by RT-PCR from ovary sample was observed in granulosa-lutea consorting with its expression in follicular growth (39). The coding sequence for GnRH receptor in ovary was identical to that reported by gonadotropes and was able to control corpus luteum function either in vitro or in vivo $(40,41)$. In human granulosa-luteal cells (hGLCs), treatment with a GnRH agonist (GnRHa) promoted down-regulation of both estrogen receptor (ER) subunit $\alpha$ and $\beta$ via the PKC system. These results showed that GnRH may contribute to control of granulosa-luteal cell function, regulating ER subunit $\alpha$ and $\beta$ expression in human ovary (42).

The GnRHR gene is also expressed in human placenta, (43). A dose-response effect of human chorionic gonadotropin 
Table I. Characteristics of GnRHR and GnRH in cancer cells.

- GnRHR and GnRH are related with proliferation and migration in cancer cells

- Expression of GnRHR and GnRH in cancer cells is very low

- There are high-affinity/low-affinity binding sites by GnRH in cancer cells

- There is no dichotomy of GnRH agonist and antagonist in cancer cells

- According with the amount of GnRHR in cell surfaces and GnRH in the media, these exert a bi-phasic impact over its extra-pituitary functions

(hCG) secretion was observed in the culture system from placental explants treated with GnRH ranging from $10^{-9}$ to $10^{-7} \mathrm{~mol} / \mathrm{l}$ (44). In primary culture of cytotrophoblast cells, choriocarcinoma cell line (JEG-3) and immortalized extravillous trophoblasts cells (IEVT), expression of an mRNA identical to its pituitary counterpart was exhibited, and an increase in GnRHR mRNA levels was observed after GnRHa treatment. This effect was reversed by adenylate cyclase inhibitor or PKA inhibitor, concluding that $\mathrm{GnRH}$ plays a regulatory function through PKC and PKA pathways in placenta (45). Another important extrahypothalamic GnRH function has been demonstrated in cultured stromal cells (46). GnRH agonist was able to abolish the tissue inhibitor function of metalloproteinase-1 and -3 (TIMP-1, TIMP-3), which are responsible for inhibiting matrix metalloproteinase (MMP) activity (47), providing evidence that $\mathrm{GnRH}$ in trophoblast cells may modulate cell invasion via MMP regulation $(46,47)$.

In rat ventral-prostate organ culture and prostate-cancer derived cells, the effect of GnRH was demonstrated on cell proliferation. GnRH receptor was able to antagonize either the testosterone actions on cell proliferation, tissue growth or it induced nuclear translocation of non-active androgen receptors (48).

The GnRH receptor is expressed in T cells (49). In this case, treatment with $\mathrm{GnRH}$ was able to encourage gene transcription of a $67-\mathrm{kDa}$ non-integrin laminin receptor, namely $67-\mathrm{kDa} \mathrm{LR}$, and also furthers cell adhesion to laminin and cell migration in vitro and in vivo (49).

GnRHR in tumors. Despite that GnRHR and GnRH transcripts from tumor cells are equivalent to pituitary coding region and protein $(3,33,50)$, there are important functional differences between them (38). In nearly all tumor cell lines, receptor expression is low in comparison with that of gonadotropes (38,51-54). Another important difference is related to $\mathrm{GnRH}$ and its receptor-binding ability. In pituitary cells, there are binding sites for $\mathrm{GnRH}$ with nanomolar dissociation constants $\left(\mathrm{K}_{\mathrm{d}}\right)$ (high affinity) $(55,56)$. In certain tumor cells, only high-affinity GnRH-binding sites could be detected $(57,58)$, or in other cases, solely low affinity GnRH-binding sites with micromolar $\mathrm{K}_{\mathrm{d}}$ values were reported (51,56,58-61). Finally, the dichotomy of GnRH agonist and antagonist does not exist in tumor cells (62) (Table I). These discrepancies could possibly explain the functional differences present between tumor and pituitary cells after receptor activation.
Function of GnRHR in tumors from non-reproductive tissues. Specific binding sites by GnRH have been reported in several tumor specimens and cancer cell lines originating from organs, which are not part of the reproductive system. These include liver (63), larynx (64), pancreas (65), colon (66), lymphoma (67), kidney $(68,69)$, skin $(70,71)$, leukemia (49) and brain (72). The function of GnRH and GnRHR in these tumors has been associated with inhibition of proliferation in a time- and dose-related manner in respond to various molecular form of $\mathrm{GnRH}$ (63-72). The response to GnRH in pancreatic tumors has been shown to be specific, it was demonstrated by the absences of binding sites for GnRH in membranes from nontumoral human pancreas tissues $(65,73)$. Experiments carried out with cytotoxic radicals linking to $\mathrm{GnRH}$ agonists, showed a potent antitumor effect over xenografts of GnRHRexpressing cells from colon carcinoma, xenografts of GnRHR-expressing cells from non-Hodking's lymphoma and xenografts of GnRHR-expressing cells from human renal cell carcinoma (RCC) $(66,69,74-76)$. The inhibition of growth of RCC xenografts in nude mice by administration of GnRH antagonist (Cetrorelix) was accompanied by a marked decrease in the number of EGF binding sites (Fig. 2A) (77). In melanoma-derived cells BLM and Me15392, GnRHR activation by Zoladex is able to support a high diminution in cell proliferation and matrigel invasion $(70,71)$; in addition, in the case of leukemia, either overexpression on cell surfaces of $67-\mathrm{kDa}$ LR cell surfaces or an increase in migration into bone marrow and spleen after GnRH stimulation was observed (49) (Fig. 2A).

Function of GnRHR in tumors from reproductive tissues. The presence of GnRHR and GnRH has been demonstrated in tumor of reproductive tract as ovarian cancer $(57,58,78,79)$, prostate cancer $(53,80-82)$, and breast cancer $(59,83,84)$. The function of these molecules in these cells remains unclear, but has been associated with cell proliferation, and migratory and invasive capacity $(71,85)$.

GnRHR and ovarian cancer. Numerous studies have demonstrated GnRH/GnRHR expression in ovarian cancer in in vitro and in vivo assays $(41,79)$. In $70 \%$ of primary ovarian cancers and $83 \%$ of primary endometrial cancers, there is expression of high-affinity/low-capacity binding sites for GnRH receptors in their surfaces, and according to recent clinical data, receptor expression is a favorable prognostic factor $(51,86,87)$. In the majority of cases, receptor activation was related with cell-proliferation inhibition $(79,86)$. For 

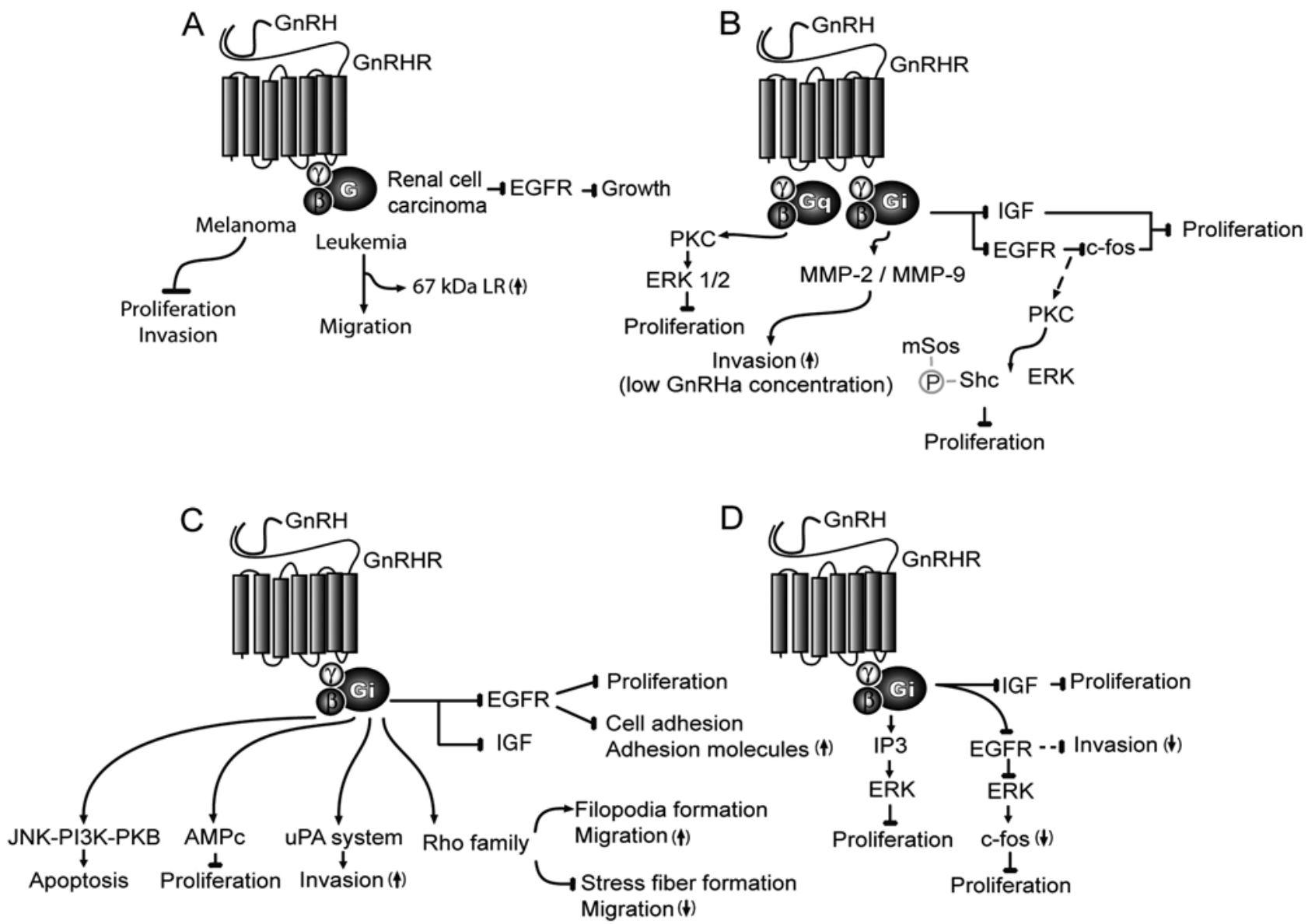

Figure 2. Signaling pathways activated by gonadotropin-releasing hormone receptor (GnRHR) in tumors from non-reproductive tissues and tumors of the reproductive tract. (A) In non-reproductive tissues GnRHR produced effects over cell proliferation and cell invasion. The signaling pathways activated by GnRHR in ovarian cancer (B), prostate cancer (C) and breast cancer (D). Coupling between GnRHR with Gi protein, cross-talk between GnRHR and growth factors receptors, and its association with different effector proteins could explain the versatility in extra-pituitary receptor function. Activation is represented by solid arrows, inhibition by a cut line, and non-well-described, by a dotted line.

human endometrial cancer cell lines (HEC-1A, Ishikawa, HHUA), GnRHR stimulation was able to down-regulate the cellular proliferation of these tumors via the PKC system $(58,88)$. This effect was misplaced when neutralizing antibodies against GnRH were employed (89). The signaling pathway by which GnRHR acts in ovarian cancer is not welldetailed, but many reports have focused on understanding the manner in which this system works. Coupling between GnRHR and $\mathrm{G}_{\mathrm{i}}$ protein in the membrane of surgically removed ovarian carcinoma and human ovarian cancer cells (Caov-3) raised the possibility that the antimitogenic action of this receptor may take place via the coupling of both molecules (33,90-92) (Fig. 2B). This interaction was linked with ERK activation and high phosphorylation levels of mSos, with the concomitant association between mSos and Shc (92) (Fig. 2B). On the other hand, mitogenic signal transduction and cell proliferation of the GnRHR effect could be associated with cross-talk between this receptor and growth factor receptors. In some ovarian cancer cells (EFO-21 and -27), GnRHR is also coupled with $G_{i}$ protein, and their activation promote phosphotyrosine phosphatase action on EGFR (33). In DU-145 cells, this receptor abrogates EGFR-induced c-fos expression and reduces the concentration of EGF-binding sites, resulting in down-regulation of cellular proliferation (93) (Fig. 2B). In nude mouse model, reduction of insulin-like growth factor I (IGF) and EGFR after GnRH analog treatment was reported (94) (Fig. 2B). In addition, GnRHR is mainly coupled with $\mathrm{G}_{\mathrm{i}}$ in ovarian-tumor cells, nevertheless in EFO-21 the antiproliferative effect of this receptor was transduced by $G_{q}$ protein (33). Activation of this $\mathrm{G}_{\mathrm{q}}$ protein could also be related with the antiproliferative effect observed in SKOV-3 and Ovacr-3 cells, in which pronounced activation of ERK1/2 via PKC after GnRH was demonstrated (95) (Fig. 2B).

The effect of GnRHR and GnRH on the invasion ability of ovarian cancer has been investigated. For ovarian-cancer cell lines, Caov-3 and OVCAR-3, JNK activation was critical for up-regulation of MMP-2 and MMP-9 after GnRHa administration. During in vitro assays a low concentration of GnRHa increased cell motility and invasiveness, but no prominent effect was shown at high concentration (96) (Fig. 2B). These results support the idea that GnRHR possesses a bi-phasic impact on cellular function in tumors from non-pituitary cells $(38,96)$ (Table I).

GnRHR and prostate cancer. Specific GnRH receptors have been found in nearly $80 \%$ malignant prostate tumors $(53,97,98)$. In these tumor cells, GnRH production was also demonstrated, suggesting a local paracrine/autocrine system 
(80). In rat prostate-cancer model, different values to GnRH receptor binding and capacities were found (99). On the other hand, specific GnRH binding sites have been reported for many tumor cell lines, such as LNCaP, an androgen-sensitive prostatic cancer cell line (100), DU145, a human androgenindependent cancer cell line (101), and PC-82, an androgendependent cell line (102). Similarly, the existence of this receptor was demonstrated in mouse and rat nude models $(103,104)$, as well as in human prostate cancer biopsy (99). Based on the above evidence, several research groups have been employing GnRH analogs as antineoplastic drugs (102,105-109). GnRHR and GnRH in prostate cancer are able to promote a high diminution in cellular proliferation $(100,101)$. However, the molecular mechanism responsible for this inhibition is unknown; notwithstanding this, a possible direct interaction between GnRH analogs and growth factor-receptor activity must be involved. Utilizing LNCaP and DU145 cells, down-regulation for EGF receptor after GnRHa treatment has been exhibited (93). Similar results were observed in DU145 cells after GnRHR activation, in which important inhibition of IGF mitogenic action was observed (110) (Fig. 2C). The signaling pathway involved in this latter process is uncertain, but at least a $\mathrm{GnRHR}-\mathrm{G}_{\mathrm{i}}{ }^{-}$ AMPc system has been associated $(82,111)$ (Fig. 2C). Another possibility for explaining the antiproliferative effect exhibited by the GnRH/GnRHR system in prostate cancer comprises direct induction of apoptotic signaling (37, $112,113)$. The signaling pathway associated with this effect is unknown; however, a previous report supports the association with JNK and the phosphatidylinositol 3'-kinase (PI3K)-protein kinase B (PKB) pathway (37) (Fig. 2C).

GnRHR and its ligand are associated with invasion and metastatic potential by inducing actin cytoskeleton remodeling. In the DU145 cell, GnRHa was able to inhibit fibroblast growth factor (FGF)-stimulated cell proliferation, invasion and the ability of these cells to recover from a cytotoxic insult by exposure to etoposide, a topoisomerase II inhibitor (108). In TSU-Pr1 cells, GnRH induced filopodia formation and increases cell migration, while in DU145 cells this hormone promotes stress-fiber formation and abolishes cell migration (114). In this latter case, the mechanism activated by $\mathrm{GnRH}$ to regulate cell migration and actin cytoskeleton was related with small $\mathrm{G}$ protein from the Rho family (Fig. 2C). The effect of GnRH on cell invasion appears to be mediated by several specific steps. In DU145 and PC3 cells, it occurs by means of the regulation of the urokinase-type plasminogen activator (uPA) system (115) and increases in cell-cell adhesion molecules $(116,117)$ (Fig. 2C). Collectively the information suggests that GnRHR activation could be associated with cell proliferation and motility in prostate cancer cells.

GnRHR and breast cancer. Specific GnRH binding sites were reported in biopsies of primary human breast carcinoma tissues (59). Nearly $50 \%$ of breast cancer specimens possess GnRH binding sites (118). For different human breast cancer cell lines (ZR-75-1, MDA-MB-231, Sk Br 3, MDA-MB-157 and MCF-7) GnRH-binding sites were reported (119). GnRHR and GnRH expression in tumoral and non-tumoral human mammary gland was tested, and no statistical differences were found at mRNA level for either the hormone or this receptor (84). The physiological function of $\mathrm{GnRH}$ and its agonist in breast cancer has been reported to inhibit the growth of cells in culture (56). In nude mouse models, complete regression of human breast carcinomas have been demonstrated experimentally (120-122), and its expression could be associated with a protective effect on the chemotherapeutic drug-produced apoptotic effect (123). Employing the adenovirus expression system, it was possible to produce a high-affinity binding site against Buserelin $(1.4 \mathrm{nM})$ and high receptor levels at the surface in the MCF-7 cell line. This cellular model was able to support increasing levels of second messenger IP3 and ERK1/2 activation and a decrease in cellular proliferation after GnRH activation (60) (Fig. 2D). In addition, cellular proliferation decreased after addition of Buserelin or other GnRH agonists, this depended either on the amount of GnRH at cell surfaces or on receptor functionality $(61,124)$. Concerning the molecular mechanism employed by GnRHR in breast cancer cells to reduce cell proliferation in MCF-7 cells, the direct inhibitory effects of Buserelin on breast cancer cells was mediated, at least in part, by an antagonists effect on the EGF receptor (125) and IGF receptor (126) (Fig. 2D). Complementary experiments were carried out in in vivo and in vitro models. In a mouse model treated with GnRH agonist, expression of both growth factor receptors was decreased (127). In 4OH-tamoxifenresistant MCF-7 and T47D-TR cells, some GnRH analogs were able to abolish cell proliferation, blocking EGF-receptor autophosphorylation, ERK1/2 activation (128), and reducing EGF-induced c-fos protein expression (129) (Fig. 2D).

Finally, reduction in the metastatic potential of several breast cancer cell lines by GnRH agonists has been demonstrated. In different breast cancer cells lines (HCC70, MCF-7, MDA-MB-435, MDA-MB-453 and T47-D), their invasive capability was increased when these were co-cultured with hOB or MG63 osteosarcoma cells. This effect was reverted after GnRH analog treatments, demonstrating receptor ability to down-regulate cell motility in this cellular model (130) (Fig. 2D).

\section{Action of GnRHR during cell motility and invasion}

The complexity of GnRHR/GnRH regulation has made it attractive for considering the involvement of multiple transducer or regulatory systems. As mentioned previously, receptor coupling with different $G$ proteins have been demonstrated. For example, association among GnRHR $_{-} \mathrm{G}_{\mathrm{q}}$, $G_{11}, G_{i}$ and $G_{s}$, in multiple mammalian cell lines such as COS7, HEK293, GH3, HeLa and CHO-K1 (35) had been shown. The $\mathrm{G}_{\mathrm{i}}$ protein is coupled with GnRHR in GT1-7 cells and primary hypothalamic cells (34). The $\mathrm{G}_{\mathrm{q}}, \mathrm{G}_{11}, \mathrm{G}_{14}$ and $G_{15}$ proteins are associated in the GGH31-cell rat gonadotrope (32). In tumor cells, GnRHR could be mainly coupling with the $G_{i}$ protein $(33,82)$. The versatility in receptor coupling with many $\mathrm{G}$ proteins might be explained within a specific cell-type context; according to cell lineage, a different receptor conformation and signaling complex might be produced (17). This information clearly suggests a possible mechanism of the manner in which GnRHR could be associated with different actions in extra-pituitary cells (35). 
Collectively the information suggests that GnRHR and GnRH form part of a sophisticated signaling pathway that is involved with many aspects of cell behavior, relating to cellular proliferation, but also with metastasis in tumor cells.

In $\alpha$ T3-1, a gonadotrope-derived cell line, GnRHR activity caused acute and dramatic changes in a cellular morphology induced by actin polymerization after ERK1/2 activation. At the same time, GnRHR was able to produce a high increase in cell motility, as well as detached cell behavior in this cellular model (131) (Fig. 1). HEK293 stably expressing GnRHR cells from rat, was able to produce either high extracellular matrix adhesion or rich actin structure or FAK, c-Src and ERK1/2 activation. It has also been demonstrated that Rac, but not RhoA, was active during GnRHR signaling (31).

In invasive human trophoblasts after GnRHR activation an increase was observed in the expression ratio of the urokinase-type plasminogen activator (uPA) and a concomitant decrease in plasminogen activator inhibitor (PAI-1) (132). Both proteins are members of a complex system related with cell migration, angiogenesis, wound healing, embryogenesis, tumor cell dissemination and metastasis in a variety of solid tumors (133). In addition, in trophoblasts GnRHR was able to increase MMP-2 and -9 at mRNA and protein levels and decreased their endogenous inhibitors TIMP-1 at mRNA and protein levels (134). This MMP activation is not only related with cell motility behavior, but also with cell proliferation via cross-talking between GnRHR and EGFR (135).

Clearly, the effect on cell motility and cell attachment was shown by cross-talk between EGFR/GnRHR. In breast cancer cells, administration of several GnRH analogs was able to produce a clear loss in EGFR function (128). In the prostate cancer cell line DU-145, GnRHR was able to produce high down-regulation in matrigel matrix invasion; this could be associated with down-regulation in EGFR expression and increases in cell-cell adhesion molecules such as E-cadherin, $\alpha$ - and $\beta$-catenin and p120 (116) (Fig. 2D).

The effect of GnRHR on cell motility and cytoskeleton must be linked with several actin-associated molecules, such as GTPases from the Rho family $(136,137)$. The principal function of these small $\mathrm{G}$ proteins is to modulate the cytoskeleton during cell locomotion in normal and tumor cells. This group is made up of six members, in which the majority of studies have been conducted on Rho, Rac and Cdc42 (138). The cellular function of Rho is to develop stress fiber and focal adhesion assembly (139). Rac is the main regulator of actin polymerization at the cellular membrane level, supporting lamellipodia and membrane-ruffling formation (140). Finally, Cdc42 supports filopodia develop-ment (141). The GTPase activity of these proteins is modulated by guanine diphosphate (GDP) or guanine triphosphate (GTP) nucleotide binding. In the active form, these proteins bind GTP, and in the inactive form, GTP is hydrolyzed to GDP. Conversion between both states is regulated by union with accessory proteins. Guanine nucleotide exchange factors (GEF) are proteins involved in the exchange of GDP by GTP. GTPase activating proteins (GAP) comprise the responsible molecules of GTP hydrolysis (142).

Many authors have established the link between activation of Rho family members and GnRHR; nonetheless, details in signaling pathways are unknown, suggesting new and interesting research opportunities.

\section{Conclusions}

Over the past decade, the presence of GnRH and GnRHR has been reported either in non-pituitary tissues or human tumors from reproductive and non-reproductive tissues or derived cell lines. These reports have associated GnRHR and GnRHR with sophisticated signaling pathways and novel functions. Coupling between this receptor and many $G$ proteins, as well as cross-talk with a certain growth factor such as EGFR, could explain how these proteins are able to control cellular proliferation and metastatic potential in nonpituitary and tumor cells. A vast body of literature suggests that GnRH and GnRHR may control their mitogenic effect via MAPK or by the induction of apoptotic signaling. On the other hand, there must be multiple targets of GnRHR for modulating the cytoskeleton during cell motility; proteins from the Rho family or their regulator proteins could be associated. The mechanisms by which diverse members of the Rho family are associated with diverse cytoskeleton proteins will aid in clarifying how these fine-tuned interactions regulate cell mobility during GnRHR activation. In this regard, understanding these novel cellular processes at the cellular and molecular levels will lead to development of new therapeutic resources in the control of tumor growth and cancer dissemination.

\section{Acknowledgements}

This study was supported by grants 83142 (to A.A.-R.) from CONACyT, México, and grant 2007-3606-14 from the FISInstituto Mexicano del Seguro Social, México (to A.A.-R.).

\section{References}

1. Conn PM, Staley D, Harris C, et al: Mechanism of action of gonadotropin releasing hormone. Annu Rev Physiol 48: 495-513, 1986.

2. Millar RP, Lu ZL, Pawson AJ, Flanagan CA, Morgan K and Maudsley SR: Gonadotropin-releasing hormone receptors. Endocr Rev 25: 235-275, 2004.

3. Kakar SS, Musgrove LC, Devor DC, Sellers JC and Neill JD: Cloning, sequencing, and expression of human gonadotropin releasing hormone $(\mathrm{GnRH})$ receptor. Biochem Biophys Res Commun 189: 289-295, 1992.

4. Pierce JG and Parsons TF: Glycoprotein hormones: structure and function. Annu Rev Biochem 50: 465-495, 1981.

5. Stojilkovic SS, Reinhart J and Catt KJ: Gonadotropin-releasing hormone receptors: structure and signal transduction pathways. Endocr Rev 15: 462-499, 1994.

6. Ulloa-Aguirre A, Janovick JA, Miranda AL and Conn PM: Gprotein-coupled receptor trafficking: understanding the chemical basis of health and disease. ACS Chem Biol 1: 631-638, 2006.

7. Harris D, Reiss N and Naor Z: Differential activation of protein kinase $\mathrm{C}$ delta and epsilon gene expression by gonadotropinreleasing hormone in alphaT3-1 cells. Autoregulation by protein kinase C. J Biol Chem 272: 13534-13540, 1997.

8. Naor Z, Benard O and Seger R: Activation of MAPK cascades by G-protein-coupled receptors: the case of gonadotropinreleasing hormone receptor. Trends Endocrinol Metab 11: 91-99, 2000.

9. Schaeffer HJ and Weber MJ: Mitogen-activated protein kinases: specific messages from ubiquitous messengers. Mol Cell Biol 19: 2435-2444, 1999. 
10. Chen Z, Gibson TB, Robinson F, et al: MAP kinases. Chem Rev 101: 2449-2476, 2001.

11. Kyriakis JM and Avruch J: Mammalian mitogen-activated protein kinase signal transduction pathways activated by stress and inflammation. Physiol Rev 81: 807-869, 2001.

12. Krens SF, Spaink HP and Snaar-Jagalska BE: Functions of the MAPK family in vertebrate-development. FEBS Lett 580: 4984-4990, 2006.

13. Segal RA and Greenberg ME: Intracellular signaling pathways activated by neurotrophic factors. Annu Rev Neurosci 19: 463-489, 1996

14. Cobb MH and Goldsmith EJ: How MAP kinases are regulated. J Biol Chem 270: 14843-14846, 1995.

15. Davis RJ: The mitogen-activated protein kinase signal transduction pathway. J Biol Chem 268: 14553-14536, 1993.

16. Seger R and Krebs EG: The MAPK signaling cascade. FASEB J 9: 726-735, 1995.

17. Dobkin-Bekman M, Naidich M, Pawson AJ, Millar RP, Seger R and Naor Z: Activation of mitogen-activated protein kinase (MAPK) by GnRH is cell-context dependent. Mol Cell Endocrinol 252: 184-190, 2006

18. Mitchell R, Sim PJ, Leslie T, Johnson MS and Thomson FJ: Activation of MAP kinase associated with the priming effect of LHRH. J Endocrinol 140: R15-R18, 1994

19. Haisenleder DJ, Cox ME, Parsons SJ and Marshall JC: Gonadotropin-releasing hormone pulses are required to maintain activation of mitogen-activated protein kinase: role in stimulation of gonadotrope gene expression. Endocrinology 139: 3104-3111, 1998.

20. Sim PJ, Wolbers WB and Mitchell R: Activation of MAP kinase by the LHRH receptor through a dual mechanism involving protein kinase $\mathrm{C}$ and a pertussis toxin-sensitive $\mathrm{G}$ protein. Mol Cell Endocrinol 112: 257-263, 1995

21. Sundaresan S, Colin IM, Pestell RG and Jameson JL: Stimulation of mitogenactivated protein kinase by gonadotropin releasing hormone: evidence for the involvement of protein kinase C. Endocrinology 137: 304-311, 1996.

22. Reiss N, Llevi LN, Shacham S, Harris D, Seger R and Naor Z: Mechanism of mitogen-activated protein kinase activation by gonadotropin-releasing hormone in the pituitary of alphaT3-1 cell line: differential roles of calcium and protein kinase $\mathrm{C}$. Endocrinology 138: 1673-1682, 1997.

23. Lin X and Conn PM: Transcriptional activation of gonadotropinreleasing hormone $(\mathrm{GnRH})$ receptor gene by $\mathrm{GnRH}$ : involvement of multiple signal transduction pathways. Endocrinology 140: 358-364, 1999

24. Roberson MS, Misra-Press A, Laurance ME, Stork PJ and Maurer RA: A role for mitogen-activated protein kinase in mediating activation of the glycoprotein hormone alpha-subunit promoter by gonadotropin releasing hormone. Mol Cell Biol 15: 3531-3539, 1995.

25. Schoderbek WE, Kim KE, Ridgway EC, Mellon PL and Maurer RA: Analysis of DNA sequences required for pituitaryspecific expression of the glycoprotein hormone alpha-subunit gene. Mol Endocrinol 6: 893-903, 1992.

26. Schoderbek WE, Roberson MS and Maurer RA: Two different DNA elements mediate gonadotropin releasing hormone effects on expression of the glycoprotein hormone alpha-subunit gene. J Biol Chem 268: 3903-3910, 1993.

27. Levi NL, Hanoch T, Benard O, et al: Stimulation of Jun Nterminal kinase (JNK) by gonadotropin-releasing hormone in pituitary alpha T3-1 cell line is mediated by protein kinase C, c-Src, and CDC42. Mol Endocrinol 12: 815-824, 1998.

28. Strahl BD, Huang HJ, Sebastian J, Ghosh BR and Miller WL: Transcriptional activation of the ovine follicle-stimulating hormone beta-subunit gene by gonadotropin-releasing hormone: involvement of two activating protein-1-binding sites and protein kinase C. Endocrinology 139: 4455-4465, 1998.

29. Maudsley S, Naor Z, Bonfil D, et al: Proline-rich tyrosine kinase 2 mediates gonadotropin-releasing hormone signaling to a specific extracellularly regulated kinase-sensitive transcriptional locus in the luteinizing hormone beta-subunit gene. Mol Endocrinol 21: 1216-1233, 2007.

30. Shah BH, Farshori MP and Catt KJ: Neuropeptide-induced transactivation of a neuronal epidermal growth factor receptor is mediated by metalloprotease-dependent formation of heparinbinding epidermal growth factor. J Biol Chem 279: 414-420, 2004 .
31. Davidson L, Pawson AJ, Millar RP and Maudsley S: Cytoskeletal reorganization dependence of signaling by the gonadotropin-releasing hormone receptor. J Biol Chem 279: 1980-1993, 2004

32. Stanislaus D, Ponder S, Ji TH and Conn PM: Gonadotropinreleasing hormone receptor couples to multiple $\mathrm{G}$ proteins in rat gonadotrophs and in GGH3 cells: evidence from palmitoylation and overexpression of $\mathrm{G}$ proteins. Biol Reprod 59: 579-586, 1998.

33. Gründker C, Völker P and Emons G: Antiproliferative signaling of luteinizing hormone-releasing hormone in human endometrial and ovarian cancer cells through $\mathrm{G}$ protein alpha(I)mediated activation of phosphotyrosine phosphatase. Endocrinology 142: 2369-2380, 2001.

34. Krsmanovic LZ, Mores N, Navarro CE, Arora KK and Catt KJ: An agonist-induced switch in $\mathrm{G}$ protein coupling of the gonadotropin-releasing hormone receptor regulates pulsatile neuropeptide secretion. Proc Natl Acad Sci USA 100: 2969-2974, 2003.

35. Knollman PE and Conn PM: Multiple G proteins compete for binding with the human gonadotropin releasing hormone receptor. Arch Biochem Biophys 477: 92-97, 2008.

36. Kraus S, Benard O, Naor Z and Seger R: c-Src is activated by the epidermal growth factor receptor in a pathway that mediates JNK and ERK activation by gonadotropin-releasing hormone in COS7 cells. J Biol Chem 278: 32618-32630, 2003.

37. Kraus S, Levy G, Hanoch T, Naor Z and Seger R: Gonadotropinreleasing hormone induces apoptosis of prostate cancer cells: role of c-Jun NH2-terminal kinase, protein kinase B, and extracellular signal-regulated kinase pathways. Cancer Res 64: 5736-5744, 2004

38. Cheung LW and Wong AS: Gonadotropin-releasing hormone: GnRH receptor signaling in extrapituitary tissues. FEBS J 275: 5479-5495, 2008

39. Peng C, Fan NC, Ligier M, Vaananen J and Leung PC: Expression and regulation of gonadotropin-releasing hormone $(\mathrm{GnRH})$ and $\mathrm{GnRH}$ receptor messenger ribonucleic acids in human granulosa-luteal cells. Endocrinology 135: 1740-1746, 1994.

40. Nathwani PS, Kang SK, Cheng KW, Choi KC and Leung PC: Regulation of gonadotropin-releasing hormone and its receptor gene expression by 17 beta-estradiol in cultured human granulosaluteal cells. Endocrinology 141: 1754-1763, 2000.

41. Choi JH, Gilks CB, Auersperg N and Leung PC: Immunolocalization of gonadotropin-releasing hormone (GnRH)-I, GnRH-II, and type I GnRH receptor during follicular development in the human ovary. J Clin Endocrinol Metab 91: 4562-4570, 2006.

42. Chiang $\mathrm{CH}$, Cheng KW, Igarashi S, Nathwani PS and Leung PC: Hormonal regulation of estrogen receptor alpha and beta gene expression in human granulosa-luteal cells in vitro. J Clin Endocrinol Metab 85: 3828-3839, 2000.

43. Iwashita M, Evans MI and Catt KJ: Characterization of a gonadotropin-releasing hormone receptor site in term placenta and chorionic villi. J Clin Endocrinol Metab 62: 127-133, 1986.

44. Lin LS, Roberts VJ and Yen SS: Expression of human gonadotropin-releasing hormone receptor gene in the placenta and its functional relationship to human chorionic gonadotropin secretion. J Clin Endocrinol Metab 80: 580-585, 1995.

45. Cheng KW, Nathwani PS and Leung PC: Regulation of human gonadotropin-releasing hormone receptor gene expression in placental cells. Endocrinology 141: 2340-2349, 2000.

46. Raga F, Casañ EM, Wen Y, Huang HY, Bonilla-Musoles F and Polan ML: Independent regulation of matrix metalloproteinase-9, tissue inhibitor of metalloproteinase-1 (TIMP-1), and TIMP-3 in human endometrial stromal cells by gonadotropin-releasing hormone: implications in early human implantation. J Clin Endocrinol Metab 84: 636-642, 1999

47. Docherty AJ, O'Connell J, Crabbe T, Angal S and Murphy G: The matrix metalloproteinases and their natural inhibitors: prospects for treating degenerative tissue diseases. Trends Biotechnol 10: 200-207, 1992

48. Maudsley S, Davidson L, Pawson AJ, Freestone SH, López de Maturana R, Thomson AA and Millar RP: Gonadotropinreleasing hormone functionally antagonizes testosterone activation of the human androgen receptor in prostate cells through focal adhesion complexes involving Hic-5. Neuroendocrinology 84: 285-300, 2006. 
49. Chen A, Ganor Y, Rahimipour S, Ben-Aroya N, Koch Y and Levite M: The neuropeptides GnRH-II and GnRH-I are produced by human $\mathrm{T}$ cells and trigger laminin receptor gene expression, adhesion, chemotaxis and homing to specific organs. Nat Med 8: 1421-1426, 2002.

50. Kakar SS, Grizzle WE and Neill JD: The nucleotide sequences of human GnRH receptors in breast and ovarian tumors are identical with that found in pituitary. Mol Cell Endocrinol 106: 145-149, 1994.

51. Chatzaki E, Bax CM, Eidne KA, Anderson L, Grudzinskas JG and Gallagher CJ: The expression of gonadotropin-releasing hormone and its receptor in endometrial cancer, and its relevance as an autocrine growth factor. Cancer Res 56: 2059-2065, 1996.

52. Kang SK, Cheng KW, Ngan ES, Chow BK, Choi KC and Leung PC: Differential expression of human gonadotropinreleasing hormone receptor gene in pituitary and ovarian cells. Mol Cell Endocrinol 162: 157-166, 2000.

53. Tieva A, Stattin P, Wikstrom P, Bergh A and Damber JE: Gonadotropin-releasing hormone receptor expression in the human prostate. Prostate 47: 276-284, 2001

54. Finch AR, Sedgley KR, Caunt CJ and McArdle CA: Plasma membrane expression of GnRH receptors: regulation by antagonists in breast, prostate, and gonadotrope cell lines. J Endocrinol 196: 353-367, 2008.

55. Wormald PJ, Eidne KA and Millar RP: Gonadotropin-releasing hormone receptors in human pituitary: ligand structural requirements, molecular size, and cationic effects. J Clin Endocrinol Metab 61: 1190-1194, 1985.

56. Miller WR, Scott WN, Morris R, Fraser HM and Sharpe RM: Growth of human breast cancer cells inhibited by a luteinizing hormone-releasing hormone agonist. Nature 313: 231-233, 1985.

57. Srkalovic G, Wittliff JL and Schally AV: Detection and partial characterization of receptors for [D-Trp6]-luteinizing hormonereleasing hormone and epidermal growth factor in human endometrial carcinoma. Cancer Res 50: 1841-1846, 1990.

58. Emons G, Ortmann O, Becker M, et al: High affinity binding and direct antiproliferative effects of LHRH analogues in human ovarian cancer cell lines. Cancer Res 53: 5439-5446, 1993.

59. Eidne KA, Flanagan CA and Millar RP: Gonadotropin-releasing hormone binding sites in human breast carcinoma. Science 229: 989-991, 1985

60. Everest H, Hislop JN, Harding T, Uney JB, Flynn A, Millar RP and McArdle CA: Signalling and antiproliferative effects mediated by GnRH receptor after expression in breast cancer cells using recombinant adenovirus. Endocrinology 142: 4663-4672, 2001 .

61. Finch AR, Green L, Hislop JN, Kelly E and McArdle CA: Signaling and antiproliferative effects of type I and II gonadotropin-releasing hormone receptors in breast cancer cells. J Clin Endocrinol Metab 89: 1823-1832, 2004.

62. Emons G, Ortmann O, Schulz KD and Schally AV: Growthinhibitory actions of analogues of luteinizing hormone releasing hormone on tumor cells. Trends Endocrinol Metabol 8: 355-362, 1997.

63. Pati D and Habibi HR: Inhibition of human hepatocarcinoma cell proliferation by mammalian and fish gonadotropin-releasing hormones. Endocrinology 136: 75-84, 1995.

64. Krebs LJ, Wang X, Nagy A, Schally AV, Prasad PN and Liebow C: A conjugate of doxorubicin and an analog of luteinizing hormone-releasing hormone shows increased efficacy against oral and laryngeal cancers. Oral Oncol 38: 657-663, 2002

65. Fekete M, Zalatnai A, Comaru-Schally AM and Schally AV: Membrane receptors for peptides in experimental and human pancreatic cancers. Pancreas 4: 521-528, 1989.

66. Szepeshazi K, Schally AV and Halmos G: LH-RH receptors in human colorectal cancers: unexpected molecular targets for experimental therapy. Int J Oncol 30: 1485-1492, 2007.

67. Keller G, Schally AV, Gaiser T, Nagy A, Baker B, Halmos G and Engel JB: Receptors for luteinizing hormone releasing hormone (LHRH) expressed in human non-Hodgkin's lymphomas can be targeted for therapy with the cytotoxic LHRH analogue AN-207. Eur J Cancer 41: 2196-2202, 2005.

68. Sion-Vardi N, Kaneti J, Segal-Abramson T, Giat J, Levy J and Sharoni Y: Gonadotropin-releasing hormone specific binding sites in normal and malignant renal tissue. J Urol 148: 1568-1570, 1992
69. Keller G, Schally AV, Gaiser T, Nagy A, Baker B, Halmos G and Engel JB: Receptors for luteinizing hormone releasing hormone expressed on human renal cell carcinomas can be used for targeted chemotherapy with cytotoxic luteinizing hormone releasing hormone analogues. Clin Cancer Res 11: 5549-5557, 2005.

70. Moretti RM, Montagnani MM, van Groeninghen JC and Limonta P: Locally expressed LHRH receptor mediate the oncostatic and antimetastastic activity of LHRH agonists on melanoma cells. J Clin Endocrinol Metab 87: 3791-3797, 2002.

71. Moretti RM, Monagnani Marelli M, van Groeninghen JC, Motta $\mathrm{M}$ and Limonta P: Inhibitory activity of luteinizing hormone-releasing hormone on tumor growth and progression. Endocr Relat Cancer 10: 161-167, 2003.

72. Van Groeninghen JC, Kiesel L, Winkler D and Zwirner M: Effects of luteinising-hormone-releasing hormone on nervoussystem tumours. Lancet 352: 372-373, 1998.

73. Fekete M, Zalatnai A and Schally AV: Presence of membrane binding sites for [D-TRP6]-luteinizing hormone-releasing hormone in experimental pancreatic cancer. Cancer Lett 45: 87-91, 1989.

74. Nagy A, Schally AV, Armatis P, et al: Cytotoxic analogs of luteinizing hormone-releasing hormone containing doxorubicin or 2-pyrrolinodoxorubicin, a derivative 500-1000 times more potent. Proc Natl Acad Sci USA 93: 7269-7273, 1996.

75. Schally AV: Luteinizing hormone-releasing hormone analogs: their impact on the control of tumorigenesis. Peptides 20: $1247-1262,1999$

76. Schally AV and Nagy A: Chemotherapy targeted to cancers through tumoral hormone receptors. Trends Endocrinol Metab 15: 300-310, 2004

77. Jungwirth A, Schally AV, Halmos G, Groot K, Szepeshazi K, Pinski J and Armatis P: Inhibition of the growth of Caki-I human renal adenocarcinoma in vivo by luteinizing hormonereleasing hormone antagonist Cetrorelix, somatostatin analog RC-160, and bombesin antagonist RC-3940-II. Cancer 82: 909-917, 1998.

78. Gründker $\mathrm{C}$ and Emons G: Role of gonadotropin-releasing hormone $(\mathrm{GnRH})$ in ovarian cancer. Reprod Biol Endocrinol 1: 65-71, 2003.

79. So WK, Cheng JC, Poon SL and Leung PC: Gonadotropinreleasing hormone and ovarian cancer: a functional and mechanistic overview. FEBS J 275: 5496-5511, 2008.

80. Limonta P, Dondi D, Moretti RM, Fermo D, Garattini E and Motta M: Expression of luteinizing hormone-releasing hormone mRNA in the human prostatic cancer cell line LNCaP. J Clin Endocrinol Metab 76: 797-800, 1993.

81. Bahk JY, Hyun JS, Lee H, Kim MO, Cho GJ, Lee BH and Choi WS: Expression of gonadotropin-releasing hormone $(\mathrm{GnRH})$ and $\mathrm{GnRH}$ receptor mRNA in prostate cancer cells and effect of GnRH on the proliferation of prostate cancer cells. Urol Res 26: 259-264, 1998.

82. Limonta P, Moretti RM, Montagnani Marelli M, Dondi D, Parenti $\mathrm{M}$ and Motta M: The luteinizing hormone-releasing hormone receptor in human prostate cancer cells: messenger ribonucleic acid expression, molecular size, and signal transduction pathway. Endocrinology 140: 5250-5256, 1999.

83. Segal-Abramson T, Kitroser H, Levy J, Schally AV and Sharoni Y: Direct effects of luteinizing hormone-releasing hormone agonists and antagonists on MCF-7 mammary cancer cells. Proc Natl Acad Sci USA 89: 2336-2339, 1992.

84. Kottler ML, Starzec A, Carre MC, Lagarde JP, Martin A and Counis R: The genes for gonadotropin-releasing hormone and its receptor are expressed in human breast with fibrocystic disease and cancer. Int J Cancer 71: 595-599, 1997.

85. Limonta P, Moretti RM, Marelli MM and Motta M: The biology of gonadotropin hormone-releasing hormone: role in the control of tumor growth and progression in humans. Front Neuroendocrinol 24: 279-295, 2003.

86. Volker P, Gründker C, Schmidt O, Schulz KD and Emons G: Expression of receptors for luteinizing hormone-releasing hormone in human ovarian and endometrial cancers: frequency, autoregulation, and correlation with direct antiproliferative activity of luteinizing hormone-releasing hormone analogues. Am J Obstet Gynecol 186: 171-179, 2002.

87. Wilkinson SJ, Kucukmetin A, Cross P, et al: Expression of gonadotrophin releasing hormone receptor I is a favorable prognostic factor in epithelial ovarian cancer. Hum Pathol 39: $1197-1204,2008$ 
88. Shibata S, Sato H, Ota H, Karube A, Takahashi $\mathrm{O}$ and Tanaka T: Involvement of annexin $\mathrm{V}$ in antiproliferative effects of gonadotropin-releasing hormone agonists on human endometrial cancer cell line. Gynecol Oncol 66: 217-221, 1997.

89. Emons G, Weiss S, Ortmann O, Gründker C and Schulz KD: LHRH might act as a negative autocrine regulator of proliferation of human ovarian cancer. Eur J Endocrinol 142: 665-670: 2000.

90. Imai A, Takagi H, Horibe S, Fuseya $\mathrm{T}$ and Tamaya $\mathrm{T}$ : Coupling of gonadotropin-releasing hormone receptor to $\mathrm{Gi}$ protein in human reproductive tract tumors. J Clin Endocrinol Metab 81: 3249-3253, 1996.

91. Imai $\mathrm{A}$, Horibe $\mathrm{S}$, Takagi $\mathrm{A}$ and Tamaya $\mathrm{T}$ : Gi protein activation of gonadotropin-releasing hormone-mediated protein dephosphorylation in human endometrial carcinoma. Am J Obstet Gynecol 176: 371-376, 1997

92. Kimura A, Ohmichi M, Kurachi $\mathrm{H}$, et al: Role of mitogenactivated protein kinase/extracellular signal-regulated kinase cascade in gonadotropin-releasing hormone-induced growth inhibition of a human ovarian cancer cell line. Cancer Res 59: 5133-5142, 1999.

93. Moretti RM, Marelli MM, Dondi D, Poletti A, Martini L, Motta $\mathrm{M}$ and Limonta P: Luteinizing hormone-releasing hormone agonists interfere with the stimulatory actions of epidermal growth factor in human prostatic cancer cell lines, LNCaP and DU 145. J Clin Endocrinol Metab 81: 3930-3937, 1996.

94. Yano T, Pinski J, Halmos G, Szepeshazi K, Groot K and Schally AV: Inhibition of growth of OV-1063 human epithelial ovarian cancer xenografts in nude mice by treatment with luteinizing hormone-releasing hormone antagonist SB-75. Proc Natl Acad Sci USA 91: 7090-7094, 1994

95. Kim KY, Choi KC, Auersperg N and Leung PC: Mechanism of gonadotropin-releasing hormone (GnRH)-I and -II-induced cell growth inhibition in ovarian cancer cells: role of the GnRH-I receptor and protein kinase C pathway. Endocr Relat Cancer 13: 211-220, 2006.

96. Cheung LW, Leung PC and Wong AS: Gonadotropin-releasing hormone promotes ovarian cancer cell invasiveness through cJun NH2-terminal kinase-mediated activation of matrix metallo-proteinase (MMP)-2 and MMP-9. Cancer Res 66: 10902-10910, 2006

97. Qayum A, Gullick W, Clayton RC, Sikora K and Waxman J: The effects of Gonadotropin releasing hormone analogues in prostate cancer are mediated through specific tumour receptors. Br J Cancer 62: 96-99, 1990.

98. Halmos G, Arencibia JM, Schally AV, Davis R and Bostwick DG: High incidence of receptors for luteinizing hormone-releasing hormone (LHRH) and LHRH receptor gene expression in human prostate cancers. J Urol 163: 623-629, 2000.

99. Fekete M, Redding TW, Comaru-Schally AM, Pontes JE, Connelly RW, Srkalovic G and Schally AV: Receptors for luteinizing hormone-releasing hormone, somatostatin, prolactin, and epidermal growth factor in rat and human prostate cancers and in benign prostate hyperplasia. Prostate 14: 191-208, 1989.

100.Limonta P, Dondi D, Moretti RM, Maggi R and Motta M: Antiproliferative effects of luteinizing hormone-releasing hormone agonists on the human prostatic cancer cell line LNCaP. J Clin Endocrinol Metab 75: 207-212, 1992.

101. Dondi D, Limonta P, Moretti RM, Marelli MM, Garattini E and Motta M: Antiproliferative effects of luteinizing hormonereleasing hormone (LHRH) agonists on human androgenindependent prostate cancer cell line DU 145: evidence for an autocrine-inhibitory LHRH loop. Cancer Res 54: 4091-4095, 1994.

102.Koppán M, Nagy A, Schally AV, Plonowski A, Halmos G, Arencibia JM and Groot K: Targeted cytotoxic analog of luteinizing hormone-releasing hormone AN-207 inhibits the growth of PC-82 human prostate cancer in nude mice. Prostate 38: 151-158, 1999.

103. Dondi D, Moretti RM, Montagnani Marelli M, et al: Growthinhibitory effects of luteinizing hormone-releasing hormone (LHRH) agonists on xenografts of the DU145 human androgen-independent prostate cancer cell line in nude mice. Int J Cancer 76: 506-511, 1998.

104. Tieva A, Wilkström P, Olofsson JI, Bergh A and Damber JE: Expression of gonadotropin-releasing hormone receptor mRNA in the rat ventral prostate and dunning R3327 PAP adenocarcinoma before and after castration. Prostate 39: 101-107, 1999.
105. Redding TW and Schally AV: Inhibition of prostate tumor growth in two rat models by chronic administration of D-Trp6 analogue of luteinizing hormone-releasing hormone. Proc Natl Acad Sci USA 78: 6509-6512, 1981.

106. Tolis G, Ackman D, Stellos A, et al: Tumor growth inhibition in patients with prostatic carcinoma treated with luteinizing hormone-releasing hormone agonists. Proc Natl Acad Sci USA 79: 1658-1662, 1982.

107. Arencibia JM, Schally AV, Halmos G, Nagy A and Kiaris H: In vitro targeting of a cytotoxic analog of luteinizing hormonereleasing hormone AN-207 to ES-2 human ovarian cancer cells as demonstrated by microsatellite analyses. Anticancer Drugs 12: 71-78, 2001.

108. Gnanapragasam VJ, Darby S, Khan MM, Lock WG, Robson CN and Leung HY: Evidence that prostate gonadotropin-releasing hormone receptors mediate an anti-tumourigenic response to analogue therapy in hormone refractory prostate cancer. J Pathol 206: 205-213, 2005

109. Gründker C, Huschmand Nia A and Emons G: Gonadotropinreleasing hormone receptor-targeted gene therapy of gynecologic cancers. Mol Cancer Ther 4: 225-231, 2005.

110. Montagnani Marelli M, Moretti RM, Dondi D and Motta M: Luteinizing hormone-releasing hormone agonists interfere with the mitogenic activity of the insulin-like growth factor system in androgen-independent prostate cancer cells. Endocrinology 76: 506-511, 1999.

111. Maudsley S, Davidson L, Pawson AJ, Chan R, López de Maturana R and Millar RP: Gonadotropin-releasing hormone $(\mathrm{GnRH})$ antagonists promote proapoptotic signaling in peripheral reproductive tumor cells by activating a Galphai-coupling state of the type I GnRH receptor. Cancer Res 64: 7533-7544, 2004.

112. Maiti K, Oh DY, Moon JS, et al: Differential effects of gonadotropin-releasing hormone (GnRH)-I and GnRH-II on prostate cancer cell signaling and death. J Clin Endocrinol Metab 90: 4287-4298, 2005.

113. Kraus S, Naor Z and Seger R: Gonadotropin-releasing hormone in apoptosis of prostate cancer cells. Cancer Lett 234: 109-123, 2006.

114.Enomoto M, Utsumi M and Park MK: Gonadotropin-releasing hormone induces actin cytoskeleton remodeling and affects cell migration in a cell-type-specific manner in TSU-Pr1 and DU145 cells. Endocrinology 147: 530-542, 2006.

115.Dondi D, Festuccia C, Piccolella M, Bologna M and Motta M: GnRH agonists and antagonists decrease the metastatic progression of human prostate cancer cell lines by inhibiting the plasminogen activator system. Oncol Rep 15: 393-400, 2006.

116. Yates C, Wells A and Turner T: Luteinising hormone-releasing hormone analogue reverses the cell adhesion profile of EGFR overexpressing DU-145 human prostate carcinoma subline. $\mathrm{Br}$ J Cancer 92: 366-375, 2005.

117. Blair HC, Wells A and Isales CM: Pituitary glycoprotein hormone receptors in non-endocrine organs. Trends Endocrinol Metabol 18: 227-233, 2007.

118. Fekete M, Wittliff JL and Schally AV: Characteristics and distribution of receptors for [D-TRP6]-luteinizing hormonereleasing hormone, somatostatin, epidermal growth factor, and sex steroids in 500 biopsy samples of human breast cancer. J Clin Lab Anal 3: 137-147, 1989.

119. Eidne KA, Flanagan CA, Harris NS and Millar RP: Gonadotropin-releasing hormone $(\mathrm{GnRH})$-binding sites in human breast cancer cell lines and inhibitory effects of GnRH antagonists. J Clin Endocrinol Metab 64: 425-432, 1987.

120. Kahán Z, Nagy A, Schally AV, Halmos G, Arencibia JM and Groot K: Complete regression of MX-1 human breast carcinoma xenografts after targeted chemotherapy with a cytotoxic analog of luteinizing hormone-releasing hormone, AN-207. Cancer 85: 2608-2615, 1999

121. Kahán Z, Nagy A, Schally AV, Halmos G, Arencibia JM and Groot K: Administration of a targeted cytotoxic analog of luteinizing hormone-releasing hormone inhibits growth of estrogen-independent MDA-MB-231 human breast cancers in nude mice. Breast Cancer Res Treat 59: 255-262, 2000.

122. Nagy A and Schally AV: Targeting of cytotoxic luteinizing hormone-releasing hormone analogs to breast, ovarian, endometrial, and prostate cancers. Biol Reprod 73: 851-859, 2005.

123. Fister S, Schlotawa L, Günthert AR, Emons G and Gründker C: Increase of doxorubicin-induced apoptosis after knock-down of gonadotropin-releasing hormone receptor expression in human endometrial, ovarian and breast cancer cells. Gynecol Endocrinol 24: $24-29,2008$ 
124. Sedgley KR, Finch AR, Caunt CJ and McArdle CA: Intracellular gonadotropin-releasing receptors in breast cancer and gonadotrope linaje cells. J Endocrinol 191: 625-636, 2006.

125. Scott WN, Mullen P and Miller WR: Factors influencing the response of MCF-7 cells to an agonist of luteinising hormonereleasing hormone. Eur J Cancer 27: 1458-1461, 1991.

126. Hershkovitz E, Marbach M, Bosin E, et al: Luteinizing hormone-releasing hormone antagonists interfere with autocrine and paracrine growth stimulation of MCF-7 mammary cancer cells by insulin-like growth factors. J Clin Endocrinol Metab 77: 963-968, 1993.

127. Szepeshazi K, Milovanovic S, Lapis K, Groot K and Schally AV: Growth inhibition of estrogen independent MXT mouse mammary carcinomas in mice treated with an agonist or antagonist of LH-RH, an analog of somatostatin, or a combination. Breast Cancer Res Treat 21: 181-192, 1992.

128. Gunthert AR, Gründker C, Olota A, Lasche J, Eicke N and Emons G: Analogs of GnRH-I and GnRH-II inhibit epidermal growth factor-induced signal transduction and resensitize resistant human breast cancer cells to $4 \mathrm{OH}$-tamoxifen. Eur J Endocrinol 153: 613-625, 2005.

129. Gründker C, Völker P, Schulz KD and Emons G: Luteinizing hormone-releasing hormone agonist triptorelin and antagonist cetrorelix inhibit EGF-induced c-fos expression in human gynecological cancers. Gynecol Oncol 78: 194-202, 2000.

130. Von Alten J, Fister S, Schulz H, Viereck V, Frosch KH, Emons G and Gründker C: GnRH analogs reduce invasiveness of human breast cancer cells. Breast Cancer Res Treat 100: 13-21, 2006.

131. Navratil AM, Knoll JG, Whitesell JD, Tobet SA and Clay CM: Neuroendocrine plasticity in the anterior pituitary: GnRH mediated movement in vitro and in vivo. Endocrinology 148: 1736-1744, 2007.

132. Chou CS, Zhu H, Shalev E, MacCalman CD and Leung PC: The effects of gonadotropin-releasing hormone $(\mathrm{GnRH}) \mathrm{I}$ and GnRH II on the urokinase-type plasminogen activator/plasminogen activator inhibitor system in human extravillous cytotrophoblasts in vitro. J Clin Endocrinol Metab 87: 5594-5603, 2002.
133. Dass K, Ahmad A, Azmi AS, Sarkar SH and Sarkar FH: Evolving role of uPA/uPAR system in human cancers. Cancer Treat Rev 34: 122-136, 2008.

134. Chou CS, Zhu H, MacCalman CD and Leung PC: Regulatory effects of gonadotropin-releasing hormone (GnRH) I and GnRH II on the levels of matrix metalloproteinase (MMP)-2, MMP-9, and tissue inhibitor of metalloproteinases-1 in primary cultures of human extravillous cytotrophoblasts. J Clin Endocrinol Metab 88: 4781-7490, 2003.

135. Roelle S, Grosse R, Aigner A, Krell HW, Czubayko F and Gudermann T: Matrix metalloproteinases 2 and 9 mediate epidermal growth factor receptor transactivation by gonadotropinreleasing hormone. J Biol Chem 278: 47307-47318, 2003.

136. Mareel $\mathrm{M}$ and Leroy A: Clinical, cellular, and molecular aspects of cancer invasion. Physiol Rev 83: 337-376, 2003.

137. Bagorda A and Parent CA: Eukaryotic chemotaxis at a glance. J Cell Sci 121: 2621-2624, 2008.

138. Aspenström P, Fransson A and Saras J: Rho GTPases have diverse effects on the organization of the actin filament system. Biochem J 377: 327-337, 2004.

139. Ridley A and Hall A: The small GTP-binding protein rho regulates the assembly of focal adhesions and actin stress fibers in response to growth factors. Cell 70: 389-399, 1992.

140. Ridley A, Paterson HF, Johnston CL, Diekmann D and Hall A: The small GTP-binding protein rac regulates growth factorinduced membrane ruffling. Cell 70: 401-410, 1992.

141. Kozma R, Ahmed S, Best A and Lim L: The Ras-related protein $\mathrm{Cdc} 42 \mathrm{Hs}$ and bradykinin promote formation of peripheral actin microspikes and filopodia in Swiss $3 \mathrm{~T} 3$ fibroblasts. Mol Cell Biol 15: 1942-1952, 1995.

142. Geyer M and Wittinghofer A: GEFs, GAPs, GDIs and effectors: taking a closer (3D) look at the regulation of Ras-related GTPbinding proteins. Curr Opinion Struct Biol 7: 786-792, 1997. 